\title{
Effect of dietary change upon the amylase and trypsin activities of the rat pancreas
}

\author{
BY FRANCES HOWARD AND JOHN YUDKIN \\ Department of Nutrition, Queen Elizabeth College, University of London
}

(Received I8 September 1962-Revised I6 fanuary 1963)

Most of the reports on enzyme adaptation, by ourselves and other workers, have been concerned with the enzymes of micro-organisms. We have, however, also made a few observations on rats, some of which have been concerned with digestive enzymes (e.g. Lawrie \& Yudkin, 1949; Roberts \& Yudkin, 1961). The work to be described was carried out as a confirmation and extension of that reported by Ivy and his colleagues (Grossman, Greengard \& Ivy, 1942-3, 1944). These workers measured the activity of three pancreatic enzymes: amylase, trypsin and lipase. Our own work is concerned with the first two.

Grossman et al. (1942-3) in their main experiment fed rats for 2I days on one of four purified diets, in which the chief differences were in the proportion of carbohydrate as starch, protein as casein and fat as lard. The control diet contained $47 \%$ starch, $18 \%$ casein and $18 \%$ fat. When the starch was increased to $67 \%$ of the diet, there was a $40 \%$ increase in the amylase activity of the pancreas and a $50 \%$ fall in the trypsin activity. When the casein was increased to $67 \%$ of the diet, there was a $20 \%$ fall in amylase activity and a threefold increase in trypsin activity. When the lard was increased to $54 \%$ of the diet, there was a $65 \%$ fall in amylase activity and no change in trypsin activity. It should perhaps be added that the four diets differed in the proportion of all three major constituents, so that, for example, the high-carbohydrate diet contained $67 \%$ starch, $15 \%$ casein and $27 \%$ lard.

In later experiments, the same workers showed that a substitution of the starch in the control diet by glucose increased amylase activity by about $20 \%$, but did not affect trypsin activity (Grossman et al. 1944). A substitution of the casein by hydrolysed casein decreased trypsin activity by about $20 \%$, but did not affect amylase activity. The daily injection of protamine zinc insulin into rats given the control diet resulted in a $30 \%$ fall in amylase activity, but did not affect trypsin activity.

\section{EXPERIMENTAL AND RESULTS}

\section{Animals}

Male albino rats were used in all the experiments. They were weaned at 23 days, and normally housed during the experiments in large cages with grids. The exceptions were the experiments with purified diets containing starch; the rats were then housed in individual cages so that they could be given vitamin supplements separately. 


\section{Procedure}

Rats were transferred at weaning either directly to the experimental diet or for a few days to the stock diet. Hokin (195I) has described considerable individual variation in amylase activity of the pancreas in pigeons. We found a similar variation between rats, and at different times of the day. Much of it could have been due to variations in secretions of pancreatic juice, stimulated by ingestion of food. We attempted to reduce the variation by removing the food from the cages at $9.30 \mathrm{a} . \mathrm{m}$. and killing the rats for enzyme measurement about $4 \mathrm{~h}$ later.

The rats were killed by a blow on the head, and the pancreas was removed immediately. It was washed in ice-cold distilled water, and, after as much as possible of the remaining fat and mesentery had been removed, it was blotted dry with filterpaper and weighed. It was then chopped with scissors, and transferred with $\mathrm{I}^{\circ} 5 \mathrm{ml}$ ice-cold water to a homogenizer consisting of a glass tube and a Perspex pestle. The homogenizer was surrounded by ice, and homogenization carried out at $2000 \mathrm{rev} / \mathrm{min}$ for $2 \mathrm{~min}$. The homogenate was filtered through a square of fine gauze and the filtrate made up to $20 \mathrm{ml}$ with water. Dry weight was determined on a $5 \mathrm{ml}$ portion by heating to constant weight at $\mathrm{I} 10^{\circ}$. Activation of trypsin was carried out on another $5 \mathrm{ml}$ portion. The activated sample and the remainder of the homogenate were stored overnight in the refrigerator for measurement the next day of trypsin and of amylase. All measurements were carried out in duplicate.

\section{Diets}

The animals had free access to the diets and to water at all times, except that the food pots were removed from the cages about $4 \mathrm{~h}$ before the animals were killed for measurement of enzymes. The stock diet consisted of cubes, supplemented by green vegetables and fresh milk daily, and by one drop weekly of vitamins $A$ and D concentrate (Adexolin; Glaxo Laboratories Ltd) (see Wiesner \& Yudkin, 195r). The purified diets, except those containing starch, were based on the standard purified diet of this laboratory. It consists of sucrose 60, low-vitamin casein 20, arachis oil I5, salts 5 , choline $0 . \mathrm{I}, \mathrm{B}$-vitamin mixture $0.05 \mathrm{~g}$, and cyanocobalamin $10 \mu \mathrm{g}$. The concentration of vitamins in $\mathrm{mg} / \mathrm{kg}$ diet was: inositol 220, nicotinic acid roo, calciumD-pantothenate $100, p$-aminobenzoic acid 75 , riboflavin 30 , pyridoxine 8 , thiamine hydrochloride 5 , folic acid $\mathrm{I}$, biotin 0.2 and cyanocobalamin 0.1 . In addition, the rats were given I $\mathrm{mg} \alpha$-tocopherol on one day a week, and on another day vitamin A I20 i.u., vitamin D 20 i.u., and menaphthone $500 \mu \mathrm{g}$. The modification of this purified diet consisted usually in changing the quantity or type of carbohydrate and casein, the two together continuing to amount to $80 \mathrm{~g} / \mathrm{r} 00 \mathrm{~g}$ diet.

The diets with starch contained, in roog, either $60 \mathrm{~g}$ maize starch and $20 \mathrm{~g}$ casein, or $3 \circ \mathrm{g}$ maize starch and $5 \circ \mathrm{g}$ casein. They were prepared by mixing together the starch and casein with $5 \mathrm{~g}$ salt. To this mixture were added $10 \mathrm{ml}$ water at $70^{\circ}$; after mixing to a smooth paste, $5 \circ \mathrm{g}$ arachis oil at $70^{\circ}$ were added. The whole was then stirred for $2-3 \mathrm{~h}$ at $70^{\circ}$ and, after cooling, the solid cake was cut into cubes. These could be kept for up to 2 weeks in a closed vessel in the refrigerator. It was not found 
possible to make satisfactory cubes from a diet with $20 \%$ starch; it was for this reason that our low-starch diet contained $30 \%$. Supplements of fat-soluble vitamins were given as for the purified diets without starch. Cyanocobalamin was given in a dose of $\mathrm{I} \mu \mathrm{g}$ weekly. The remaining B vitamins were given daily as $\mathrm{I} \mathrm{ml}$ of solution containing choline chloride 5 , inositol I.I, nicotinic acid 0.5 , calcium-D-pantothenate 0.5 , $p$-aminobenzoic acid 3 , riboflavin 0.15 , pyridoxine 0.04 , thiamine hydrochloride 0.025 , folic acid 0.002 and biotin $0.001 \mathrm{mg}$.

\section{Measurement of enzyme activity}

Amylase. The method of Smith \& Roe (I949) for amylase in blood has been modified for the much higher amylase activity in our pancreatic homogenate. The method is based on the decrease in the intensity of blue colour given by the reaction of starch and iodine as the starch is hydrolysed. Instead of $\mathrm{r} \cdot 2 \mathrm{~g}$ starch/100 $\mathrm{ml}$, and an incubation time of $30 \mathrm{~min}$, we used $2 \mathrm{~g}$ starch/100 $\mathrm{ml}$ and an incubation time of $10 \mathrm{~min}$. The starch solution was prepared by making a paste of $2 \mathrm{~g}$ Lintner's soluble starch with a little cold water and pouring it into a boiling mixture of phosphate buffer $33 \mathrm{ml}, \mathrm{N}-\mathrm{NaCl} 5.5 \mathrm{ml}$, and water $45 \mathrm{ml}$. After boiling for $3 \mathrm{~min}$, the solution was cooled and made up to $100 \mathrm{ml}$. The starch solution was made afresh for each experiment, since it deteriorated even when kept overnight in the refrigerator. The phosphate buffer, $\mathrm{pH} 7 \cdot 2$, was made by dissolving $7 \cdot 62 \mathrm{~g}$ anhydrous $\mathrm{KH}_{2} \mathrm{PO}_{4}$ and $51 \cdot 5 \mathrm{~g}$ $\mathrm{Na}_{2} \mathrm{HPO}_{4} \cdot \mathrm{I}_{2} \mathrm{H}_{2} \mathrm{O}$ in I 1 . water. The iodine reagent contained $6 \mathrm{~g}$ iodine and $60 \mathrm{~g} \mathrm{KI}$ in I l. water.

A boiling tube containing $10 \mathrm{ml}$ starch solution was placed in a water-bath at $37^{\circ}$ for about Io min, I $\mathrm{ml}$ pancreatic homogenate suitably diluted was added, and after exactly $10 \mathrm{~min}$ the reaction was stopped by the addition of $2 \mathrm{ml} \mathrm{N}-\mathrm{H}_{2} \mathrm{SO}_{4}$. Into a $250 \mathrm{ml}$ volumetric flask containing about $200 \mathrm{ml}$ water were measured $5 \mathrm{ml} \mathrm{N}-\mathrm{H}_{2} \mathrm{SO}_{4}$, I $\mathrm{ml}$ iodine reagent and $2 \mathrm{ml}$ incubation mixture, and water was then added to $250 \mathrm{ml}$. The standard was prepared by placing $5 \mathrm{ml}$ starch solution and $5 \mathrm{ml}$ water in a boiling tube and adding $2 \mathrm{ml} \mathrm{N}-\mathrm{H}_{2} \mathrm{SO}_{4}$ and $\mathrm{I} \mathrm{ml} \mathrm{pancreatic} \mathrm{homogenate.} \mathrm{Portions} \mathrm{of} 2 \mathrm{ml}$ were taken and the colour was developed in $250 \mathrm{ml}$ volumetric flasks as above. Comparisons of colour were made in a Hilger Spekker absorptiometer with a filter with maximum absorption at $620 \mathrm{~m} \mu$ and cells of $\mathrm{I} \mathrm{cm}$ width.

Calibration curves were made for each experiment with 5,7 and $10 \mathrm{ml}$ of starch solution. There was strict proportionality between enzyme concentration and degree of hydrolysis between 100 and $200 \mathrm{mg}$ starch hydrolysed, and the initial dilution of pancreatic homogenate was made so as to give an activity within this range. The original method of Smith \& Roe (1949) showed proportionality only between $\circ$ and $40 \mathrm{mg}$ starch hydrolysed.

We have used an empirical unit of amylase activity, which we define as the amount in $\mathrm{r} \mathrm{mg}$ dry weight of tissue that will hydrolyse $20 \mathrm{mg}$ starch in to min to a stage giving no colour with iodine as measured at $620 \mathrm{~m} \mu$.

Proteolytic activity. The method was adapted from those of a number of authors, including Kunitz (1946-7) and Gad (1948). After treatment of the pancreatic extract with enteropeptidase, total proteolytic activity at $\mathrm{pH} 8$ was measured by digestion of 
casein and measurement of liberated phenolic groups in the trichloroacetic-acid-soluble fraction. No attempt was made to separate the activities of trypsin and chymotrypsin; we have nevertheless followed customary usage in referring to the activity we have measured as 'trypsin'.

Preparation of enteropeptidase. The enzyme was prepared by the method of Hawk, Oser \& Summerson (1954). The duodenal mucosa from four freshly killed pigs was scraped with a glass slide. The material was shaken with 3 vol. of acetone and left to stand for $2 \mathrm{~h}$. The residue was filtered off, washed with acetone, then with a mixture of acetone and diethyl ether, and finally twice with diethyl ether. The residue was dried in air and pulverized. It was kept in the refrigerator and parts of it were taken for the whole series of experiments described in this paper.

Activation of trypsin. The activation was carried out with $0.1 \mathrm{~g}$ enteropeptidase powder, which was ground with $5 \mathrm{ml}$ phosphate buffer, $0.05 \mathrm{M}$ at $\mathrm{pH} 6.3$. After centrifugation, I $\mathrm{ml}$ of supernatant liquid was added to I $\mathrm{ml}$ pancreatic extract in a Io $\mathrm{ml}$ volumetric flask. The mixture was incubated for $15 \mathrm{~min}$ at $37^{\circ}$, and then made up to ro $\mathrm{ml}$. The activity of the sample was measured after it had been kept at $4^{\circ}$ overnight, during which period the activity had not changed.

Substrate. Hammarsten's casein, $0.3 \mathrm{~g}$, was suspended in $90 \mathrm{ml} 0.1 \mathrm{M}$-phosphate

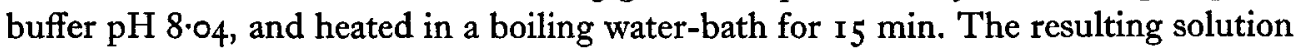
was cooled and made up to $100 \mathrm{ml}$ with buffer. It kept without deterioration for 2 weeks at $4^{\circ}$.

Measurement of tryptic activity. Casein solution, $5 \mathrm{ml}$, was placed in a boiling tube in a water-bath at $37^{\circ}$ and I ml enzyme solution added. After exactly ro min the reaction was stopped by the addition of $4 \mathrm{ml} 10 \%(\mathrm{w} / \mathrm{v})$ trichloroacetic acid. A blank solution was prepared by adding $4 \mathrm{ml}$ acid to $5 \mathrm{ml}$ casein solution, and then $\mathrm{Iml}$ enzyme solution. After I 3 min the mixture was filtered through Whatman no. 2 paper. To $5 \mathrm{ml} \mathrm{N}-\mathrm{NaOH}$ solution in a $25 \mathrm{ml}$ flask were added $5 \mathrm{ml}$ filtrate and $\mathrm{I} \mathrm{ml}$ phenol reagent of Folin and Ciocalteau (British Drug Houses Ltd). The volume was made up to $25 \mathrm{ml}$ and, after Io min for the colour to develop, the blue colour was read in the Hilger Spekker absorptiometer with Ilford filter $700 \mathrm{~m} \mu$ (no. 608) and cells $\mathrm{I} \mathrm{cm}$ in width. Standard curves were produced by developing the colour of known amounts of tyrosine from 0.05 to $0.25 \mathrm{mg}$. We define a unit of tryptic activity as the amount in I $\mathrm{mg}$ dry weight of tissue which in 10 min gives a colour equal to that given by $0.05 \mathrm{mg}$ pure L-tyrosine.

\section{Preliminary experiments}

Expt 1. From 3 to 4 days after weaning, six rats were fed for 2 weeks on the diet containing $20 \%$ sucrose and $60 \%$ casein, instead of the usual $60 \%$ sucrose and $20 \%$ casein. They showed a reduction by about one-half in amylase activity, and an increase by about one-half in trypsin activity.

Expt 2. Three rats were fed for 3 weeks on either of the diets used in Expt I (first period). Each group was then changed over to the other diet for 2 weeks (second period). At the end of this time, the enzyme activities were found to be similar to those of rats kept for the whole of the time on the diets of the second period. Thus, 
the enzyme changes induced by the high- or low-sucrose diets of the first period were reversed by the changed diets during the second period.

Expt 3. From 4 days after weaning groups of three rats were fed for 16 days on normal or high-protein diets, but with 60 or $20 \%$ glucose or fructose instead of sucrose. Trypsin activity was the same with all these sugars. Amylase activity was also the same with all three sugars at dietary levels of $20 \%$. At $60 \%$ sugar, fructose caused the same amylase activity as did sucrose, but glucose caused amylase activity about $50 \%$ higher than did sucrose or fructose. In other words, whereas an increase in dietary sucrose or fructose from 20 to $60 \%$ doubled amylase activity, an increase in dietary glucose by the same amount trebled amylase activity.

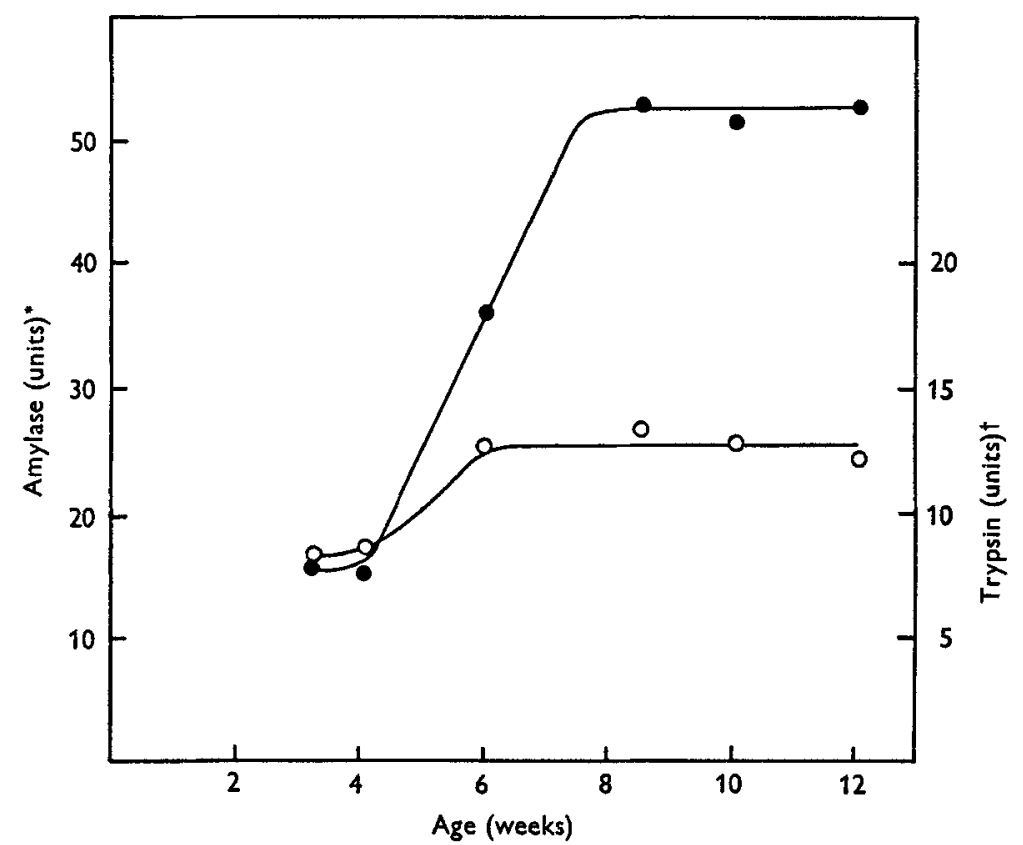

Fig. I. Change with age in amylase and trypsin activities in the pancreas of rats fed on a stock diet. $\bullet \longrightarrow$, amylase; $\multimap \longrightarrow$, trypsin. * See p. 283 . + See p. 284 .

Change in enzyme activities with increasing age: stock diet

Expt 4. Rats were fed from weaning on the stock diet as described earlier. Enzyme activities were measured in four to seven rats at intervals from the day of weaning at 23 days to 12 weeks of age.

It will be seen (Fig. I) that amylase activity increased more than threefold between the ages of 4 and 7 weeks, and then did not change. Tryptic activity also increased, mostly between 4 and 6 weeks, but by only about $60 \%$.

Effect of change from high-to low-sucrose diets, or from low-to high-sucrose diets

Expt $5 a$. Twenty-four rats were weaned on to the basal purified diet with $60 \%$ sucrose and $20 \%$ casein. After I week, twelve of the rats were put on to the diet with $20 \%$ sucrose and $60 \%$ casein. Enzyme measurements were carried out on about half of the animals in each group after a further $\mathrm{r}_{4}$ days and on the remainder after 22 days. 
After 2 weeks, rats on the low-sucrose diet had significantly less amylase activity and significantly more trypsin activity than rats on the high-sucrose diet (Table I). During the next week there was a significant increase in amylase activity with the $60 \%$ sucrose diet; the other changes were not significant.

Expt $5 b$. To determine how rapidly the change in enzyme activity occurs, enzyme measurements were carried out on the day the diet was changed, and I day and 7 or 8 days thereafter. Thirty rats were weaned on to diets containing either $60 \%$ sucrose or $20 \%$ sucrose. After I week, half of each group was changed over to the other diet. Owing to the inadvertent loss of some of the samples of pancreas before dry weights could be determined, all the results in this experiment have been quoted per mg wet weight of tissue.

Table I. Effect of change from a high-sucrose to a low-sucrose diet on amylase and trypsin activities in the rat pancreas

(Rats fed for $\mathrm{I}$ week from weaning on diet with $60 \%$ sucrose and $20 \%$ casein. Then half of them changed to diet with $20 \%$ sucrose and $60 \%$ casein, and half kept on same diet. Days of experiment counted from change. Mean values with standard deviations)

\begin{tabular}{|c|c|c|c|c|}
\hline $\begin{array}{c}\text { Sucrose } \\
\text { in diet } \\
(\%)\end{array}$ & $\begin{array}{l}\text { No. of } \\
\text { rats/group }\end{array}$ & $\begin{array}{l}\text { Duration of } \\
\text { experiment } \\
\text { (days) }\end{array}$ & $\begin{array}{l}\text { Amylase } \\
\text { (units)* }\end{array}$ & $\begin{array}{l}\text { Trypsin } \\
\text { (units) }\end{array}$ \\
\hline $\begin{array}{l}60 \\
20\end{array}$ & $\begin{array}{l}7 \\
6\end{array}$ & $\begin{array}{l}14 \\
14\end{array}$ & $\begin{array}{l}25.5 \pm 6.7 \\
13.8 \pm 4.8\end{array}$ & $\begin{array}{l}11 \cdot 7 \pm 2 \cdot 1 \\
17 \cdot 3 \pm 3 \cdot 7\end{array}$ \\
\hline $\begin{array}{l}60 \\
20\end{array}$ & $\begin{array}{l}5 \\
6\end{array}$ & $\begin{array}{l}22 \\
22\end{array}$ & $\begin{array}{l}32 \cdot 9 \pm 4 \cdot 6 \\
15 \cdot 0 \pm 3.1\end{array}$ & $\begin{array}{l}10.1 \pm 0.7 \\
14.8 \pm 2.3\end{array}$ \\
\hline
\end{tabular}

It will be seen from Fig. 2 that the differences in the preliminary dietary treatment again produced differences in the amount of enzyme activity. The diet with $60 \%$ sucrose caused more amylase activity and less trypsin activity than did the diet with $20 \%$ sucrose. The curves show that the effects of this diet on both amylase and trypsin activities are reversible. The increase and decrease of trypsin activity with the decrease and increase of dietary sucrose occurred within $\mathrm{I}$ day. The corresponding changes in the amylase activity occurred more slowly, mostly after the Ist day.

\section{Changes in enzyme activity with increasing age: purified diets}

Expt $6 a$. The experiments with casein-sucrose diets having extended for no longer than 3 weeks, a similar but more prolonged experiment was undertaken. Thirty-four rats were fed from weaning on a diet with $60 \%$ sucrose and $20 \%$ casein. After I week, half of them were changed to the diet with $20 \%$ sucrose and $60 \%$ casein, and enzyme measurements were carried out at intervals for 8 further weeks. During this time the growth rates of the rats in the different groups were not significantly different, and were the same as of rats kept on the laboratory stock diet.

As before, there was more amylase activity when the diet contained $60 \%$ sucrose than when it contained $20 \%$ (Table 2). In this experiment, the differences after I week on the different diets were small. Though the amount of amylase activity continued to increase with age on both diets, the increase was much greater between 
the Ist and 2nd weeks on the diet with $60 \%$ sucrose. From 2 to 8 weeks, amylase activity remained about twice that found when the diet with less sucrose was used.

Also in line with the previous results was the fact that there was much more trypsin activity in rats fed on the $60 \%$ casein diet after I week. Unlike with amylase, however, the trypsin activity did not increase with either diet between 2 and 8 weeks. This finding was also in contrast to that in the experiment with the stock diet, which produced an increase of about $60 \%$ in tryptic activity between 4 and 6 weeks.

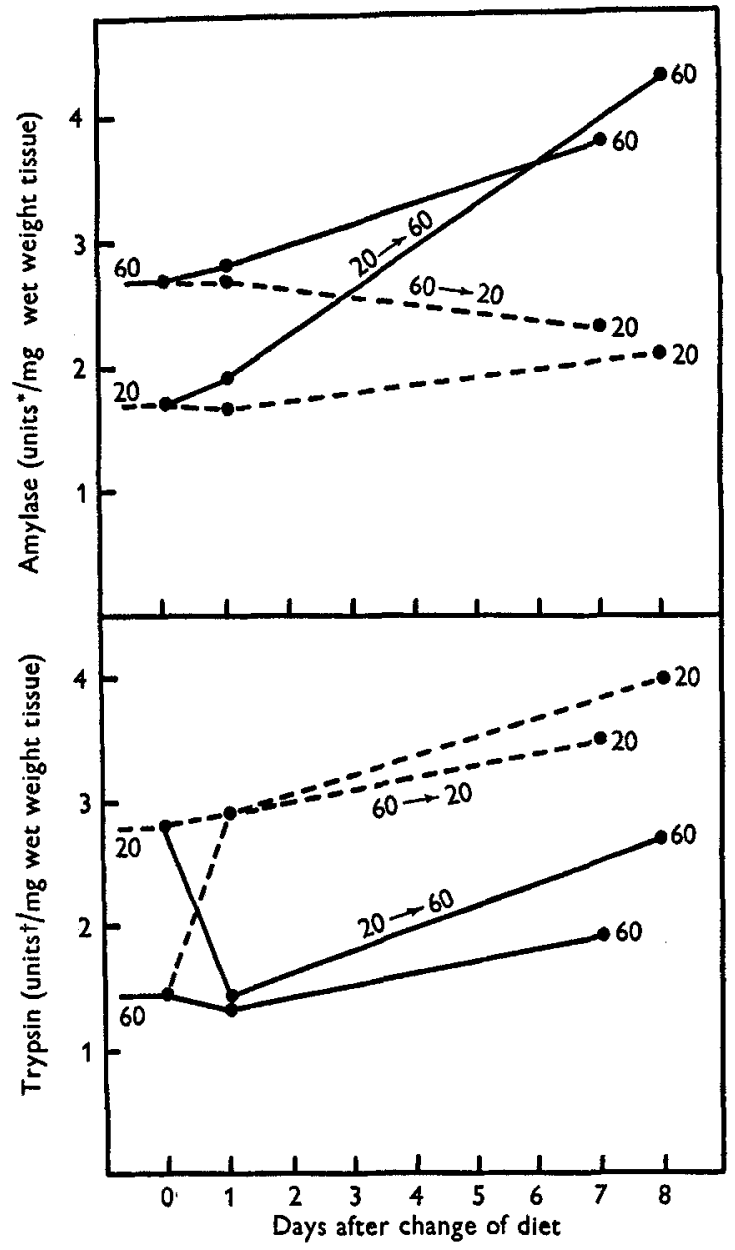

Fig. 2. Change in amylase and trypsin activities in the pancreas of rats changed from highto low-sucrose diets, ox from low- to high-sucrose diets. Rats were weaned on to diets containing either $60 \%$ sucrose $(60)$ or $20 \%$ sucrose (20). After I week, half of each group was changed on to the other diet $(60 \rightarrow 20$ or $20 \rightarrow 60)$. - , rats on $60 \%$ sucrose diet; --- , rats on $20 \%$ sucrose diet. * See p. 283 . † See p. 284 .

Expt $6 b$. An experiment similar to Expt $6 a$ was carried out at the same time, but with starch instead of sucrose. One diet contained $60 \%$ starch with $20 \%$ casein; the second diet contained $30 \%$ starch with $50 \%$ casein. This experiment lasted for 6 weeks after the rats had received for I week from weaning the standard diet of $60 \%$ sucrose 
and $20 \%$ casein. Twenty-eight rats were used, and the rates of growth were again not significantly different from those of rats on the other diet.

The effects of the diets high and low in starch were, on the whole, the same as of those containing sucrose (Table 3). The only difference was that the effect of starch

Table 2. Effect of age on amylase and trypsin activities in the pancreas of growing rats on a diet with 60 or $20 \%$ sucrose

(Rats fed on diet containing 60\% sucrose and $20 \%$ casein, or $20 \%$ sucrose and $60 \%$ casein, from weaning at 23 days. Mean values with standard deviations)

Diet with $60 \%$ suctose

\begin{tabular}{|c|c|c|c|}
\hline $\begin{array}{c}\text { Weeks } \\
\text { after } \\
\text { weaning }\end{array}$ & $\begin{array}{l}\text { No. of } \\
\text { rats/ } \\
\text { group }\end{array}$ & $\begin{array}{l}\text { Amylase } \\
\text { (units)* }\end{array}$ & $\begin{array}{l}\text { Trypsin } \\
\text { (units) } \dagger\end{array}$ \\
\hline I & 3 & $9.9 \pm 0.5$ & $8 \cdot 1 \pm 0.6$ \\
\hline 2 & 3 & $2 I^{\prime} 5 \pm 3 \cdot 8$ & $10 \cdot 4 \pm \mathrm{I} \cdot \mathrm{I}$ \\
\hline 4 & 3 & $30.7 \pm 3.9$ & $10.7 \pm 0.9$ \\
\hline 6 & 3 & $39 \cdot 8 \pm 5 \cdot 1$ & $10.7 \pm 0.5$ \\
\hline 8 & 3 & $5 I \cdot I \pm 6 \cdot 2$ & $9 \cdot 8 \pm \mathrm{r} \cdot 2$ \\
\hline
\end{tabular}

Diet with $20 \%$ sucrose

\begin{tabular}{|c|c|c|}
\hline $\begin{array}{c}\text { No. of } \\
\text { rats/ } \\
\text { group }\end{array}$ & $\begin{array}{l}\text { Amylase } \\
\text { (units)* }\end{array}$ & $\begin{array}{l}\text { Trypsin } \\
\text { (units) } \dagger\end{array}$ \\
\hline 3 & $8 \cdot 2 \pm 0.3$ & $15 \cdot 7 \pm I \cdot 2$ \\
\hline 4 & $9 \cdot 2 \pm I \cdot 2$ & $14.7 \pm 3.0$ \\
\hline 6 & I $2 \cdot 7 \pm 1 \cdot 3$ & $13 \cdot 7 \pm I \cdot I$ \\
\hline 3 & $18.6 \pm 3.2$ & I $5 \cdot 9 \pm I \cdot 7$ \\
\hline 3 & $23.8 \pm 4.7$ & I $5.6 \pm 1 \cdot 9$ \\
\hline
\end{tabular}

Table 3. Effect of age on the amylase and trypsin activities in the pancreas of growing rats on a diet with 60 or $30 \%$ starch

(Rats fed on diet with $60 \%$ starch and $20 \%$ casein, or with $30 \%$ starch and $50 \%$ casein, from weaning at 23 days. Mean values with standard deviations)

Diet with $60 \%$ starch

Weeks No. of
after rats/
weaning group

$\begin{array}{cc}\begin{array}{c}\text { Amylase } \\ \text { (units)* }\end{array} & \begin{array}{c}\text { Trypsin } \\ \text { (units) } \dagger\end{array} \\ 19.0 \pm 3.2 & 9.1 \pm 2.1 \\ 37.6 \pm 5.2 & 13.4 \pm 0.7 \\ 32.8 \pm 4.8 & 10.4 \pm 2.7 \\ 50.0 \pm 6.3 & 10.4 \pm 2.1\end{array}$

Diet with $30 \%$ starch

$\begin{array}{ccc}\begin{array}{c}\text { No. of } \\ \text { rats/ } \\ \text { group }\end{array} & \begin{array}{c}\text { Amylase } \\ \text { (units) }\end{array} & \begin{array}{c}\text { Trypsin } \\ \text { (units) }\end{array} \\ 4 & 10.9 \pm 1.9 & 18.0 \pm 1 \cdot 9 \\ 3 & 10.6 \pm 2.8 & 13.5 \pm 0.9 \\ 3 & 18.4 \pm 3.1 & 14.9 \pm 0.5 \\ 3 & 25.7 \pm 5.2 & 17.9 \pm 2.4\end{array}$

* See p. 283 . † See p. 284 .

Table 4. Effect of kind of dietary carbohydrate on amylase and trypsin activities in the rat pancreas

(Rats fed for I week from weaning on diet with $60 \%$ sucrose, then on diet with 60 or $20 \%$ glucose or fructose. Mean values with standard deviations)

Days on
glucose or
fructose
diet
I4
I4
2 I
21

Diet with $60 \%$ sugar

Carbohydrate

Glucose

Fructose

Glucose

Fructose

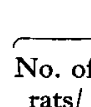

rats/

group

3

-

3

3

$$
40 \cdot 2 \pm 4 \cdot 7
$$

$26 \cdot 3 \pm 3 \cdot 8$

$\begin{array}{ll}\text { Amylase } & \text { Trypsin } \\ \text { (units)* } & \text { (units) } \dagger\end{array}$

No.

$\begin{array}{ccc}\begin{array}{c}\text { No. of } \\ \text { rats/ } \\ \text { group }\end{array} & \text { Amylase } & \text { (units)* }\end{array}$

$28 \cdot 1 \pm 3 \cdot 0 \quad$ I $1 \cdot 9 \pm x \cdot 9$

$10.5 \pm 0.2$

IO. I $\pm \mathrm{I} \cdot \mathrm{I}$

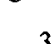

$9 \cdot 5 \pm I \cdot 8$

$10.0 \pm 1 \cdot 1$

$15 \cdot 0 \pm 2 \cdot 1$

3

$12 \cdot 5 \pm 0 \cdot 6$

I3.3 $\pm 2 \cdot 0$

$17 \cdot 2 \pm 1 \cdot 8$

* See p. 283 . † See p. 284 . 
on amylase activity was greater than the effect of sucrose. The fact that the diet with $30 \%$ starch caused more amylase activity than that with $20 \%$ sucrose may have been due to the difference in the amount of carbohydrate. But there was also the same effect when either starch or sucrose was present at the same level of $60 \%$ in the diet.

\section{Effect of glucose and fructose on enzyme activity}

Expt 7. Twenty-one rats were fed for I week from weaning on a diet with $60 \%$ sucrose. They were then transferred to one of four diets, containing 60 or $20 \%$ glucose, or 60 or $20 \%$ fructose. Enzyme activities were measured after I4 days and 2I days. As with sucrose, the level of tryptic activity was greater with $20 \%$ carbohydrate than with $60 \%$ carbohydrate (Table 4). However, no difference was found with the different sugars. Again, there was more amylase activity with the $60 \%$ level of carbohydrate than with the $20 \%$ level. At the level of $20 \%$, the kind of sugar made no difference to amylase activity. However, after 2I days, and with the sugars at a level of $60 \%$, fructose produced the same activity as sucrose, whereas the activity produced by glucose- 40.2 units-was significantly greater $(P<0.01)$ than that produced by sucrose. It was also greater than the value of 32.9 produced by sucrose after 22 days in Expt $5^{a}$ (Table I) or that of 30.7 after 4 weeks from weaning in Expt $6 a$ (Table 2).

\section{Table 5. Effect of glycerol or sorbitol in diet on amylase and trypsin activities in the rat pancreas}

(Rats fed for I week from weaning on diet with $60 \%$ sucrose, then I week on diet with $10 \%$ glycerol or sorbitol, then 2 weeks on diet with $20 \%$ glycerol or sorbitol. Four rats in each group. Mean values with standard deviations)

\begin{tabular}{|c|c|c|}
\hline $\begin{array}{l}\text { Carbohydrate } \\
\text { substitute }\end{array}$ & $\begin{array}{c}\text { Amylase } \\
\text { (units) }\end{array}$ & $\begin{array}{l}\text { Trypsin } \\
\text { (units) }\end{array}$ \\
\hline $\begin{array}{l}\text { Glycerol } \\
\text { Sorbitol }\end{array}$ & $\begin{array}{r}10 \cdot 8 \pm 2 \cdot 3 \\
7 \cdot 2 \pm 1 \cdot 2\end{array}$ & $\begin{array}{l}I 4.8 \pm 2 \cdot 9 \\
I 7 \cdot 4 \pm 3.3\end{array}$ \\
\hline
\end{tabular}

\section{Effect. of glycerol and sorbitol on enzyme activity}

Expt 8. Glycerol could not be given at levels higher than $20 \%$. Sorbitol was given for 7 days at $10 \%$ and a further 7 days at $20 \%$; immediate introduction of $20 \%$ sorbitol into the diet of the rat causes severe diarrhoea (Morgan \& Yudkin, 1957).

Four weanling rats were fed on a diet with $10 \%$ glycerol and $70 \%$ casein for I week, and on a diet with $20 \%$ glycerol and $60 \%$ casein for a further 2 weeks. Another four rats were given similar diets, but with sorbitol instead of glycerol. The diets with glycerol gave the same values for both enzymes as the diets with sucrose, glucose or fructose (Table $5 ; \mathrm{cf}$. Tables $\mathrm{I}$ and 4 ). The diets with sorbitol appeared to give rather less amylase activity, and rather more trypsin activity, but the differences were not significant. 


\title{
Effect of carbohydrate-free diet on enzyme activity
}

Our experiments have shown that lowering the proportion of sugar from $60 \%$ of the diet to $20 \%$ decreased amylase activity; the concomitant increase of casein from 20 to $60 \%$ increased the level of trypsin. The effect was now studied of diets free from sugar, which meant also raising the level of casein to $80 \%$ of the diet.

Expt 9. Three days after weaning, eight rats were put on a carbohydrate-free diet with $80 \%$ casein. Enzyme activity was measured after 28 days. The amylase activity was $5 \cdot 3 \pm 0 \cdot 1$ units and trypsin activity $19 \cdot 3 \pm 2 \cdot 1$ units. The value for amylase was thus about $50 \%$ less, and that for trypsin about $40 \%$ more, than the values in animals in Expt $6 a$ receiving the diet with $20 \%$ sucrose (see Table 2). These differences assessed by the within-experiment error variability were significant at the $\mathrm{I} \%$ level.

\section{Effect of hydrolysed casein diet on enzyme activity}

Amylase activity was about the same after rats were fed on diets with either the substrate of the enzyme, starch, or its hydrolysis product, glucose, at low or high levels. It was of interest, therefore, to see whether a tryptic digest of casein would give values for pancreatic trypsin similar to those given by casein itself.

\section{Table 6. Effect of hydrolysis of dietary casein on amylase and trypsin activities in the rat pancreas}

\begin{abstract}
(Rats fed for I week from weaning on diet with $60 \%$ sucrose and $20 \%$ casein, then for 2 weeks on diet with $60 \%$ sucrose and $20 \%$ hydrolysed casein, or $20 \%$ sucrose and $60 \%$ hydrolysed casein. Three rats in each group. Mean values with standard deviations)
\end{abstract}

$\begin{array}{ccc}\begin{array}{c}\text { Hydrolysed } \\ \text { casein } \\ \text { in diet } \\ (\%)\end{array} & \begin{array}{c}\text { Amylase } \\ \text { (units)* }\end{array} & \begin{array}{c}\text { Trypsin } \\ \text { (units) } \dagger\end{array} \\ 20 & 26 \cdot 0 \pm 3 \cdot 2 & 5 \cdot 7 \pm 0 \cdot 9 \\ 60 & 11 \cdot 4 \pm 2 \cdot 4 & 9 \cdot 2 \pm 1 \cdot 2 \\ & * \text { See p. 283. † See p. 284. }\end{array}$

Expt Io. It was possible to obtain only a small quantity of a tryptic digest of dried skim milk, with a reduced proportion of lactose. Its percentage composition, as given by the manufacturers (Benger's Laboratories Ltd) was: hydrolysed protein 70 , fat $\mathrm{x} \cdot 0$, lactose 10.5 , ash 8.5 , moisture Io; ratio, free amino $\mathrm{N}$ : total amino $\mathrm{N} 60 \%$. Two diets were constructed, containing either 20 or $60 \%$ 'protein' on the dry basis; they were thus equivalent to the casein-containing diet used in earlier experiments. There was enough of the hydrolysed casein to feed only three rats on each diet for I4 days. They were fed for I week after weaning on the basal diet with $20 \%$ casein before being placed on the experimental diet. The rats on the diet with $20 \%$ hydrolysed casein gained about $4 \circ \mathrm{g}$ weekly, somewhat less than the $5^{\circ} \mathrm{g}$ or so in the previous experiments with casein; those on the $60 \%$ hydrolysed casein diet gained only about $20 \mathrm{~g}$ weekly.

Amylase activity was not significantly different from that found with the casein diet 
(Table 6; cf. Table $\mathrm{x}$ ). There was more trypsin activity with the higher level of hydrolysed casein than with the lower level, but there was less trypsin activity at both levels than found with diets containing the same amount of casein.

\section{Effect of change from high- to low-sucrose diets in older rats}

The experiments so far described were carried out on rats 4 weeks old at the beginning of each experiment. We now examined the effect of changing from the $60 \%$ sucrose diet to the $20 \%$ sucrose diet in animals 12-18 weeks old.

Expt Ir. Twenty-seven rats were fed on the laboratory stock diet for from 9 to II weeks from weaning. They were then given the basal purified diet with $60 \%$ sucrose for I week. After this time, the diet of twelve rats was changed to that with $20 \%$ sucrose and $60 \%$ casein. Enzyme measurements were carried out for a further I, 7 and 14 days.

Table 7 shows that, with $60 \%$ sucrose, there was more amylase activity in these older animals than in the younger animals, but there was no difference in trypsin activity (cf. Expts $5 a, b$ ). As before, the change from the high to the low level of sucrose led to a slow fall in amylase activity and a rapid rise in trypsin activity. The change in amylase activity was seen after I week and continued during the and week. The change in trypsin activity was seen after I day.

\section{Table 7. Effect of change from high-sucrose to low-sucrose diet on amylase and trypsin activities in the pancreas of older rats}

(Rats fed for 9-11 weeks from weaning on laboratory stock diet, then I week on diet with $60 \%$ sucrose and $20 \%$ casein. Then half of them changed to diet with $20 \%$ sucrose and $60 \%$ casein, and half kept on same diet. Days of experiment counted from change. Mean values with standard deviations)

\begin{tabular}{|c|c|c|c|c|c|c|}
\hline \multirow{2}{*}{$\begin{array}{c}\text { Duration } \\
\text { of } \\
\text { experi- } \\
\text { ment } \\
\text { (days) }\end{array}$} & \multicolumn{3}{|c|}{ Diet with $60 \%$ sucrose } & \multicolumn{3}{|c|}{ Diet with $20 \%$ sucrose } \\
\hline & $\begin{array}{l}\text { No. of } \\
\text { rats/ } \\
\text { group }\end{array}$ & $\begin{array}{l}\text { Amylase } \\
\text { (units)* }\end{array}$ & $\begin{array}{l}\text { Trypsin } \\
\text { (units)† }\end{array}$ & $\begin{array}{l}\text { No. of } \\
\text { rats/ } \\
\text { group }\end{array}$ & $\begin{array}{l}\text { Amylase } \\
\text { (units)* }\end{array}$ & $\begin{array}{l}\text { Trypsin } \\
\text { (units) } \dagger\end{array}$ \\
\hline 0 & 3 & $54^{\prime 2} \pm 4 \cdot 3$ & $10 \cdot 1 \pm \mathrm{I} \cdot 5$ & 一 & 一 & 一 \\
\hline $\mathbf{I}$ & 3 & $5 I \cdot 0 \pm 4 \cdot 9$ & $1 x \cdot 8 \pm 0.5$ & 3 & $60 \cdot 2 \pm 9 \cdot 8$ & $15 \cdot 8 \pm 0.2$ \\
\hline $\begin{array}{r}7 \\
\times 4\end{array}$ & $\begin{array}{l}3 \\
6\end{array}$ & $\begin{array}{l}45 \cdot 0 \pm I \cdot 0 \\
45 \cdot 2 \pm 6 \cdot 4\end{array}$ & $\begin{array}{r}9.9 \pm 1.2 \\
10.6 \pm \text { I. }\end{array}$ & $\begin{array}{l}3 \\
6\end{array}$ & $\begin{array}{l}25 \cdot 0 \pm 4.2 \\
16.3 \pm 3.4\end{array}$ & $\begin{array}{l}13 \cdot 8 \pm 1 \cdot 7 \\
16 \cdot 7 \pm 2 \cdot 3\end{array}$ \\
\hline
\end{tabular}

\section{DISCUSSION}

The results reported here demonstrate several features, both qualitative and quantitative. They include, for example, the much greater increase with age in amylase activity than in that of trypsin, and the rapid change in trypsin activity with dietary change compared with the much slower change in amylase activity. In our present stage of knowledge, however, it seems profitless to discuss some of these findings.

Nevertheless, one feature is worth some comment, and that is the adaptive response of these enzymes to the components of the diet. The diets in our first experiments were varied by changing the proportion of sucrose and casein from the $60: 20$ of our 
standard basal diet. It might then have been said that, for example, the effect of changing this proportion to sucrose 20 and casein 60 , which decreased the level of amylase and increased the level of trypsin, could have been due either to the decrease in the proportion of sucrose, or to the increase in the proportion of casein. Our later experiments, however, revealed that by keeping the nature as well as the proportion of the protein component constant, but varying the nature of the carbohydrate, we were able to affect the amylase but not the trypsin activity. Thus, with $20 \%$ casein, tryptic activity was unaltered by substitution for sucrose of either starch, glucose, fructose, sorbitol or glycerol. But amylase activity was significantly lower with the last three than with starch or glucose. The converse was also true, so that changing the protein from casein to hydrolysed casein did not change amylase activity but reduced tryptic activity. We conclude, therefore, that the enzyme activities are affected independently, by change in the proportion and the nature of the carbohydrate or of the protein in the diet.

If we define adaptation as purposeful change in the organism, brought about by a change in the environment, then the increase or decrease in amylase or trypsin activity is adaptive in that it follows an increase or a decrease in dietary starch or dietary protein. Since, however, neither of these substances is absorbed as such, the factor which stimulates the pancreas to produce the appropriate enzyme can only be the product of hydrolysis. With amylase, we can say that our observations fit this suggestion, at least in part. Both starch and glucose, when present in large amounts in the diet, produced more amylase activity than did other substances. In our experiments, too, starch and glucose were equally effective in this respect, so that we have not been able to confirm the findings of Grossman et al. (1942-3, I944) that glucose produces more amylase activity than does starch. Yet it is clear that fructose and sucrose also stimulate amylase production, since when the level of these sugars was raised from 20 to $60 \%$ in the diet, amylase activity was doubled.

One might have expected that sucrose, giving on hydrolysis an equal mixture of glucose and fructose, would cause a level of amylase activity somewhere between the levels produced by fructose and glucose. The fact that it did not do so may have something to do with the speed at which the hydrolysis products are absorbed into the blood and so reach the pancreas.

Since glucose caused as much amylase activity as the substrate starch, it seemed possible that a tryptic hydrolysate of casein would cause as much tryptic activity as the substrate casein. As we have seen, however, it did not do so. This may well have been due to the fact that the digestion of casein and other proteins in vivo leads to the release of amino acids in ratios which are not the same as in the final hydrolysed product. Thus the substances reaching the pancreas when unhydrolysed casein is given are not in the same proportion as those reaching it when the completely hydrolysed casein is given. If one were to state this situation teleologically, one would say that the pancreas is stimulated to produce more enzyme when it is called upon to digest more protein, and that the stimulus comes from the products of the digestion as they are produced in the body. 
SUMMARY

I. The effects of alteration in diet upon the amylase and trypsin activities of the pancreas were studied in male albino rats.

2. In rats fed on the laboratory stock diet, both amylase and trypsin activities increased with age, amylase activity increasing by more than threefold during the 2 months after weaning, and trypsin activity by about $60 \%$ in a somewhat shorter time. Rats fed on a purified diet with $60 \%$ sucrose and $20 \%$ casein showed a similar increase of about fourfold in amylase activity but a smaller and quicker increase in trypsin activity.

3. When the purified diet contained $20 \%$ sucrose and $60 \%$ casein, the amylase activity was about $50 \%$ lower, and the trypsin activity about $50 \%$ higher, than when it contained $60 \%$ sucrose and $20 \%$ casein.

4. Rats whose diets were changed from high-sucrose, low-casein to low-sucrose, high-casein showed a decrease in amylase activity and an increase in tryptic activity. Rats whose diets were changed in the opposite direction showed the opposite change in enzyme activities.

5. The change in amylase activity occurred between I and 7 days after the change in the dietary sucrose: casein ratio. The change in tryptic activity occurred in less than $24 \mathrm{~h}$.

6. The effect was studied of diets with two levels of starch, glucose, or fructose, and one level of sorbitol or glycerol, instead of sucrose. Tryptic activity was unaffected by changes at the level of 60 or $20 \%$ in the diet. Amylase activity was also unaffected by changes at the level of $20 \%$. At $60 \%$, starch and glucose produced about $50 \%$ more amylase activity than did sucrose or fructose.

7. The substitution of hydrolysed casein for $60 \%$ or $20 \%$ casein in the diet did not affect amylase activity. It reduced tryptic activity by nearly half.

8. The lowest values for amylase activity were found when rats were fed on a carbohydrate-free diet with $80 \%$ casein. These were one-sixth of the highest values, found when rats were fed on a diet with $60 \%$ starch or glucose.

9. The lowest values for trypsin activity were found when rats were fed on a diet with $20 \%$ hydrolysed casein. These were one-third of the highest values, found when rats were fed on the diet with $80 \%$ casein.

10. Thus, amylase and trypsin activities are affected independently by changing the proportion or nature of the carbohydrate or protein in the diet.

We take this opportunity of recording our gratitude to Genatosan Ltd and to the Energen Foods Company for their generous support of the research programme of this laboratory, and the British Empire Cancer Campaign for a personal grant to one of us (F.H.). 


\section{REFERENCES}

Gad, I. (1948). Dansk Tidsskr. Farm. 22, 277.

Grossman, M. I., Greengard, H. \& Ivy, A. C. (1942-3). Amer. J. Physiol. 138, 676. Grossman, M. I., Greengard, H. \& Ivy, A. C. (1944). Amer. J. Physiol. r41, 38.

Hawk, P. B., Oser, B. L. \& Summerson, W. H. (1954). Practical Physiological Chemistry, I $3^{\text {th }}$ ed. London: Churchill.

Hokin, L. E. (1951). Biochem. F. 48, 320.

Kunitz, M. (1946-7). F. gen. Physiol. 30, $29 x$.

Lawrie, N. R. \& Yudkin, J. (I949). Biochem. F. 45, 438.

Morgan, T. B. \& Yudkin, J. (1957). Nature, Lond., r80, 543.

Roberts, A. H. \& Yudkin, J. (I961). Brit. F. Nutr. r5, 457.

Smith, B. W. \& Roe, J. H. (I 949). F. biol. Chem. 179, 53.

Wiesner, B. P. \& Yudkin, J. (I95I). Nature, Lond., r67, 979. 